\title{
Discovery of the Northeast Passage: the Voyage of the VEGA, 1878-1879
}

\author{
Prof. Dr. George Kish, The University of Michigan, Annarbor, MI, 48109; USA
}

On the evening of September 2, 1879, a small, black vessel, flying the Swedish flag, anchored in the harbor of Yokohama, Japan. Two men were taken ashore by the small barkass of the vessel, they went straight to the telegraph station, anxious to send a telegram to Europe. The clerk told them that, because of floods in Siberia, the telegram would have to be sent via India, and the two men did not have enough cash to pay the high cost of the message. A European standing in the telegraph office then introduced himself as the Russian consul in Yokohama, and the two men in turn introduced themselves: Adolf Erik Nordenskiöld was the leader of the Swedish expedition aboard the vessel, Vega, Louis Palander, a Swedish naval officer, was the vessel's skipper. The Russian diplomat, delighted to meet these two distinguished travellers, offered to advance the cost of the wire, and the message was sent to Oscar II, King of Sweden and Norway, in Stockholm:

"The Swedish expedition sends greetings to their high patron. Program fulfilled. Northeast Passage executed. An ocean opened to navigation without loss of a single man, without illness, and without damage to the vessel".

One of the last great sea voyages of all time thus came to a successful conclusion. A small, steam-driven vessel, manned by thirty men, accomplished a feat that Europeans have attempted many times during the previous three centuries, a sea voyage from Europe past the shores of Siberia to Bering Strait and the Pacific.

Few people outside Sweden paid much attention to the departure of Vega for its epochal voyage, in July, 1878. Its return from Japan, sailing around much of the Old World through the South China Sea, the Indian Ocean, the Suez Canal, the Mediterranean, and the Atlantic was reported by the world's press in detail. Vega's arrival in Stockholm, on April 24, 1880, is still celebrated by a formal lecture and dinner, and by the day being called "Vega Day" in the Swedish calendar.

The practical results of the voyage at the time were few, occasional sailings from Europe to the Arctic harbors and river mouths of Siberia. But its long-range implications are very much evident to-day, when the Northern Seaway of the Soviet Union, from Europe via Siberia to the Pacific, is a going concern.

Reading the report on the voyage one is struck by the lack of high adventure, by the comfort the men aboard enjoyed during a long Siberian winter when the ship was frozen in, by the perfectly routine occupations of scientists, officers, and crew pursued during extreme climatic conditions. The Vega expedition remains one of the most successful Arctic voyages of all time, and one of the first voyages when scientific concerns had a higher priority than the excitement of "being first". The credit for this must go to the organizer, Adolf Nordenskiöld, who summed it up in this way, some years after his return:

"I am not a hero. I was not interested in reaching the North Pole. I was merely concerned with finding the way to the Orient, getting my men and myself over there and back home. I am only a practical geographer".

Adolf Nordenskiöld, the man who organized and commanded the remarkable expedition to the Northeast Passage, was a native of Finland. When he was born, in 1832, Finland was part of the Russian Empire, though it retained many of the traditions of Swedish rule that ended in 1809. The Nordenskiölds, like the majority of the intellectual, commercial and political leaders of Finland came originally from Sweden, and though they had lived in Finland for well over a century, they had retained ties with the country of their forebears. The family was distinguished by members who made their name in the arts and sciences: Adolf Nordenskiöld's father 


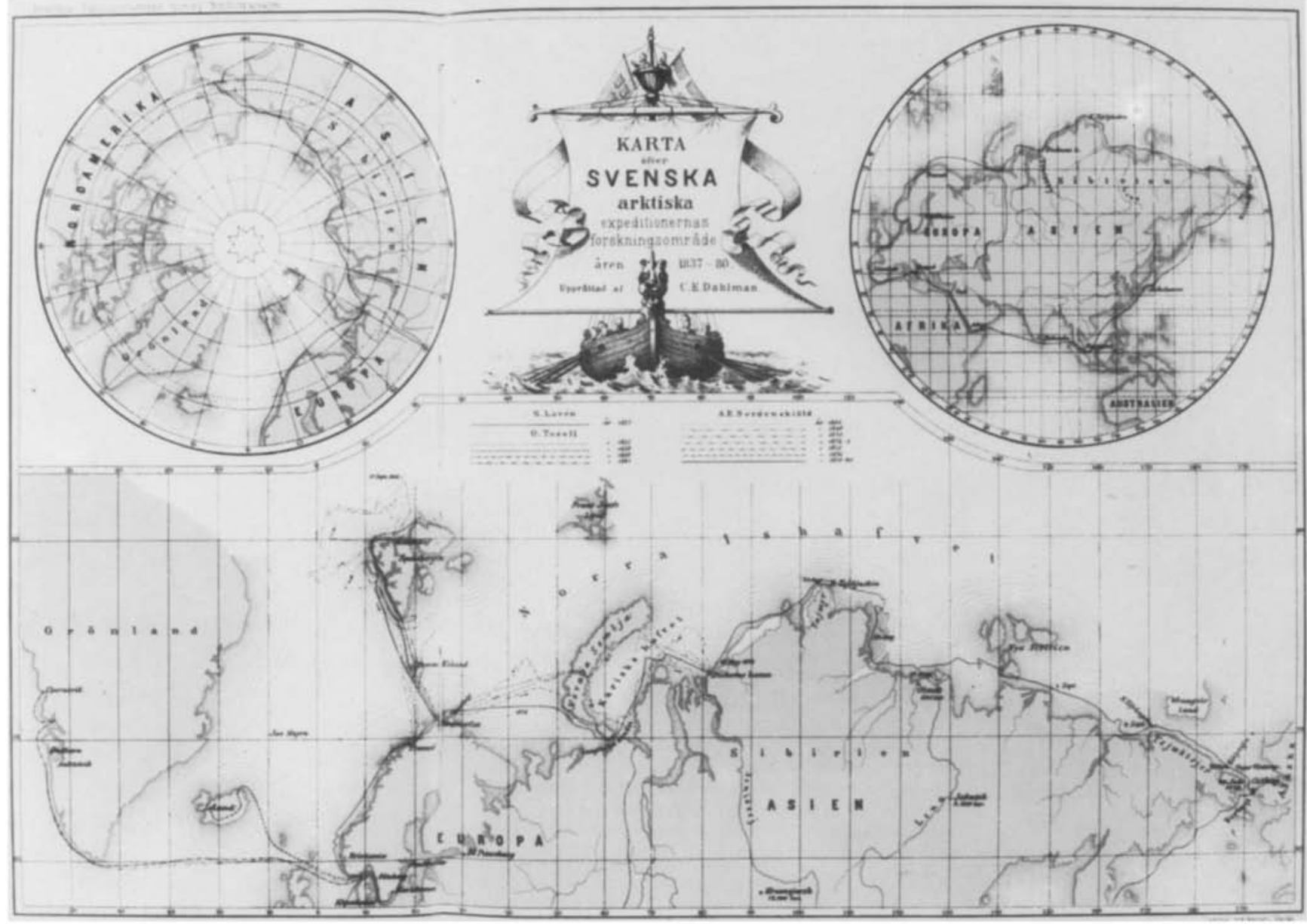

Fig 1 A map of Swedish arctic voyages showing the Vega expedition. Publ. Stockholm 1881.

was a mineralogist, and his son followed in his footsteps, getting his degree in geology and mineralogy at the University of Helsingfors.

When he received his degree in 1857, the memories of the Crimean War were still very much alive, and the Russian authorities in Finland were unusually sensitive to any open criticism of Russian rule. Nordenskiöld, speaking at a graduation banquet, spoke in public in a manner the Russians interpreted to be rebellious, and his chances of advancement, of a University career, seemed very dim indeed. Nordenskiöld chose to leave Finland for Sweden, that was to become his permanent home.

His career in Sweden was swift and spectacular. After a first journey to Spitsbergen, on a scientific expedition as a geologist, he found himself chosen to become, at the age of twenty-six, head of the division of mineralogy at the National Museum of Sweden, with the courtesy title of Professor. For the next twenty years he worked as a museum administrator, pursued his scientific studies and, most importantly, made seven journeys to the Arctic. Few if any of his contemporaries were as well qualified as Nordenskiöld to undertake a major exploratory journey to the Far North.
Four of the expeditions that Nordenskiöld participated in during those years were to Spitsbergen, in $1861,1864,1868$, and 1872-1873. On one of the journeys, in 1868, the expedition, under the leadership of Nordenskiöld, established a record: on September 18, 1868, Sofia, the small steamer of the expedition, reached 81 degrees 42 minutes north latitude, the furthest north any vessel had reached up to that time.

There was another reason that the 1868 expedition was an important one. Getting funds for scientific expeditions was not easy in those days, yet Nordenskiöld was able to enlist the support of the prosperous business community of Göteborg, Sweden's principal port. The leading contributor to the 1868 expedition was the man considered the wealthiest of all Swedes, Oscar Dickson, a Göteborg industrialist. Dickson was bitten by the fever of excitement that goes with exploration and discovery, and became a close friend and unwavering supporter of Nordenskiöld's arctic voyages.

By 1872, Nordenskiöld collected enough funds to hire a steamship and crew, and purchase enough supplies, for a fifteen-month stay in Spitsbergen. His aim was to attempt a sled journey to the North Pole. Through a 
series of unforeseen and unavoidable misadventures, the 1872-1873 expedition failed in its principal purpose. In fact, the expedition was frozen in on Spitsbergen, and survived only by careful planning and expert medical care. In a sense, it was a dress rehearsal for what was to happen later, in 1878, when Vega was frozen in off the coast of northeast Siberia.

There was another reason Nordenskiöld considered the experience of 1872-1873 important. The commander of his ship was a Swedish naval officer, Louis Palander, who had served on Sofia in 1868, and who proved himself a tower of strength during the grim winter in Spitsbergen. It was on the basis of that experience that, five years later, Nordenskiöld asked the Swedish Navy to second Palander as skipper of Vega.

The 1870's saw intense activity in Arctic waters. While Nordenskiöld and his expedition were marooned in Spitsbergen, the Austrian vessel Tegethoff was beset in sea ice, and drifted across the Arctic Ocean, discovering the archipelago, Franz Josef Land, in 1873. More importantly, Karl Weyprecht, one of the leaders of the Tegethoff expedition, proposed in 1875 that, instead of being bent on breaking records of higher and higher latitudes achieved, Arctic discovery should concentrate on a scientific exploration of the Arctic environment. In 1882-83, Weyprecht's proposal led to the first International Polar Year. It may also haven strengthened Adolf Nordenskiöld's belief in the importance of scientific investigations as part of polar exploration.

Siberia has long been on Nordenskiöld's mind, ever since his student days, and he did approach the Russian government in the early 1870 's with a proposal to organize a "hydrographic and scientific expedition" to Siberia. There seems to have been little interest in Russian government and scientific circles in the project, even though much of the pioneer work in Arctic waters off Siberia was done by Russians and foreigners in Russian service, during the 18th century. But Nordenskiöld did find support in Sweden, principally in the person of Oscar Dickson. Encouraged by that support, Nordenskiöld continued to gather information from a variety of sources on the waters of the Arctic north of Europe and of Siberia.

Norwegian fishermen and whalers have sailed across Arctic seas for a very long time, and in the late 1860's and in 1870 several made journeys into the Kara Sea. In 1870, one Tromsö skipper, Edvard Johannesen, sailed clear around Novaya Zemlya, proving to Nordenskiöld's satisfaction that traversing that part of the Arctic Ocean was feasible.

The hypothesis upon which Nordenskiöld based his notion of a voyage across the Northeast Passage had its basis in the vast volume of water spilled by the rivers of Siberia into the Arctic Ocean. The $\mathrm{Ob}^{\prime}$, the Yenisei, the Lena, the rivers of northeast Siberia, provided relatively warm, certainly ice-free water, and if a ship could sail around Cape Chelyuskin, the northernmost extremity of Eurasia, it could accomplish the feat of sailing from Europe to the Pacific.

To prove the hypothesis, Nordenskiöld persuaded Dickson to charter a small Norwegian fishing vessel, Pröven. On June 8, 1875, Nordenskiöld, four other scientists, and a crew of twelwe sailed from Tromsö for the Russian Arctic. They found the waters between Novaya Zemlya and the continent open, and on August 13, the ship reached the mouth of the Yenisei. They landed on a small island that Nordenskiöld named Dickson Island, in honor of his patron. The island retains its name to this day: on the mainland opposite Dickson Island the Soviet government maintains one of the most important air and marine bases of the Northern Sea Route, named Dickson.

The expedition split up at Dickson. Having established the navigability of the waters between Norway and northwest Siberia, the ship Pröven returned to Norway. Nordenskiöld and five of his companions started a trip up the Yenisei, to furnish proof that waterborne commerce between Europe and the interior of Siberia was indeed possible. They started with their own rowboat, but a few days later were taken in tow by a small steamboat plying the river, and after almost two months, their slow vessel landed them in Yeniseisk, in the settled part of Siberia.

Nordenskiöld and his companions then made the long journey back to European Russia, to Moscow, en route to Sweden. While in Moscow, Nordenskiöld spoke to the Russian Society for the Development of Merchant Shipping on the possibilities of seaborne commerce between Europe and Siberia. A young Russian in the audience, Alexander Sibiriakoff, heir to a great business and mining fortune, was in the audience, and on his return to Stockholm Nordenskiöld got a telegram from him: Sibiriakoff offered a substantial sum of money, 25,000 rubles, towards the expenses of another voyage from Norway to Siberia, to furnish added proof of the practicability of that sea route.

In 1876, Nordenskiöld made a second trip to the Yenisei, starting again in north Norway, and his backers in Sweden and in Russia were convinced that the time was ripe to attempt a voyage across the Northeast Passage to the Orient. In his report on the 1876 trip, Nordenskiöld wrote: "I am convinced, and this conviction is shared by the fishermen and sealers with whom I spoke here, that regular sailings between Siberia and northern Europe present neither greater difficulties nor greater perils than those met by sailors on seaways used by thousands of ships every year."

King Oscar II, the ruling sovereign of Sweden and Norway, was very much interested in the possibility of an expedition opening up the long-sought Northeast Passage. On January 26, 1877, the king invited Nordenskiöld, his principal backer, Oscar Dickson, the scientists who accompanied Nordenskiöld on the Yenisei sailings in 1875 and 1876, and others to a dinner, to discuss the project. 


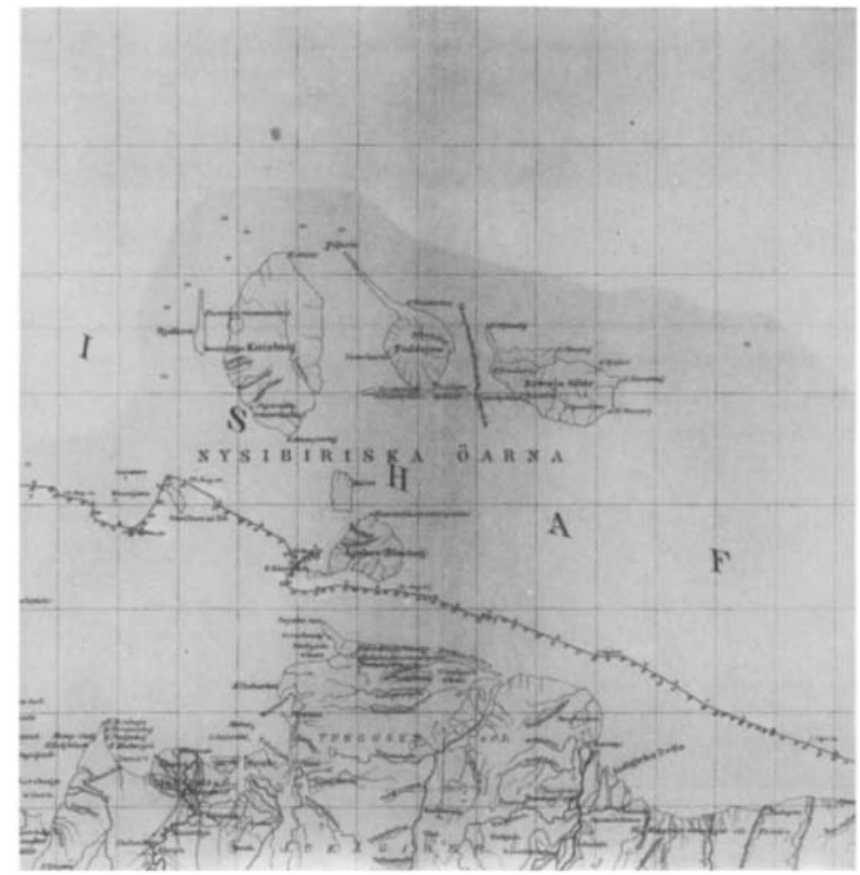

Fig 2 Part of the map of Vega's route from: Vega's färd Kring gam'avärlden. Stockholm 1881.

The final outcome of that evening was the promise of financial backing by the king himself. The funds for the expedition came from several sources. Dickson contributed nearly two-thirds, $62 \%$ of the total of 710,000 Swedish kronor, at that time approximately 185,000 dollars. Alexander Sibiriakoff contributed $15 \%$, King Oscar II, $10 \%$, the Swedish government, $13 \%$.

This was to be Adolf Nordenskiöld's ninth journey to the Arctic, and his preparations witness his knowledge of that environment, his awareness of its dangers, and his careful weighing of all of the evidence available on the navigability of Arctic waters.

Nordenskiöld contacted the United States Navy, partly because of the voyage of a US man-of-war, Vincennes, to the waters off northeastern Siberia, in 1855; partly because he hoped to get reports through the American Navy on the experiences of American whalers north of Bering Strait. Through his Russian backer, Sibiriakoff, he also gathered intelligence on the waters off the Siberian coast. The Russian reports admitted that the Arctic Ocean off northeast Siberia was likely to be icefree, but at the same time warned that it was impossible to define the period when these waters were open for navigation. "Everything depends on the state of drift ice: it is not dangerous when the weather is calm, but the slightest wind can spell disaster for ships, piling up ice against the coastline, where it mercilessly destroys anything in its way."

Having compiled the best available information on the navigability of the waters he planned to traverse, Nordenskiöld turned his attention to the purchase of a ship for the voyage. The vessel chosen was built in Bremer- haven, in 1873, of oak, but with an extra cover, made of greenheart, a tropical hardwood, to protect it from ice. It was not a large ship, it measured 38 meters along the keel, 43 meters on her deck, with a beam of 8 meters, and a rated capacity of 357 tons. The ship, renamed Vega, had a brig-type rigging and a small steam engine, two longboats, and a steam-driven barge. It was a powerful, well-built vessel. Nordenskiöld had asked the Swedish Navy to second Louis Palander, who had been with him in the Arctic in 1868 and $1872-73$, to command the ship of the expedition; it was Palander who inspected the vessel and, on his advice, Dickson advanced the money to purchase it.

Dr, Envall, who was surgeon for the 1872-73 expedition to Spitsbergen, provided Nordenskiöld with advice on planning the food supply for the expedition. The Swedish Navy inspected Vega at the Karlskrona Navy yard, stocked it with coal and provisions for a two-year journey, and recruited a volunteer crew of regular Navy men to serve aboard the ship. Vega flew, besides the Swedish flag, the colors of the Royal Swedish Sailing Society, the Navy having refused permission for the ship to use the flag of a man-of-war.

Palander was Vega's skipper, with Lieutenant Erik Brusewitz, also an officer in the Swedish Navy, as his second-in-command. Lieutenant Andreas Hovgaard, of the Danish Navy, served as astronomer-meteorologistgeophysicist; Lieutenant Giacomo Bove, of the Italian Navy, was navigator-hydrographer; Lieutenant Oscar Nordquist, a Finn serving in the Finnish rifle regiment of the Russian Army, was the expedition's Russian interpreter and, as it turned out, its all-round linguist.

Nordenskiöld was in overall command of the expedition. Frans Kjellman, who had been in the Arctic with Nordenskiöld in 1872-73, and in 1875, was the expedition's botanist. Anton Stuxberg, a veteran of the 1875 and 1876 sailings to the Yenisei, was the expedition's zoologist. The ship's doctor, Ernst Almquist, who was an amateur zoologist, and Boström, a taxidermist, rounded out the scientific staff. Two non-commissioned officers, fifteen enlisted men of the Swedish navy, and three Norwegian harpooners completed the crew.

The presence of non-Swedes on the expedition was the result of Nordenskiöld's world-wide contacts with scientists, whom he had asked to recommend particularly well-qualified men for his staff. It also assured, if not financial backing, at least strong interest in the fate of the expedition in Denmark, in Finland, and in Italy.

Vega left the Karlskrona Navy yard, on June 22, 1878 , and proceeded to the north Norwegian port of Tromsö, where Nordenskiöld was to join the expedition. At Tromsö, three other vessels joined Vega, to form a regular squadron, at least as far as the mouth of the Yenisei.

Sibiriakoff, the Russian co-sponsor of the expedition, 
Fig 3 Vega frozen in at Pitlekaj, NE Siberia. Contemporary litograph cca. 1881.

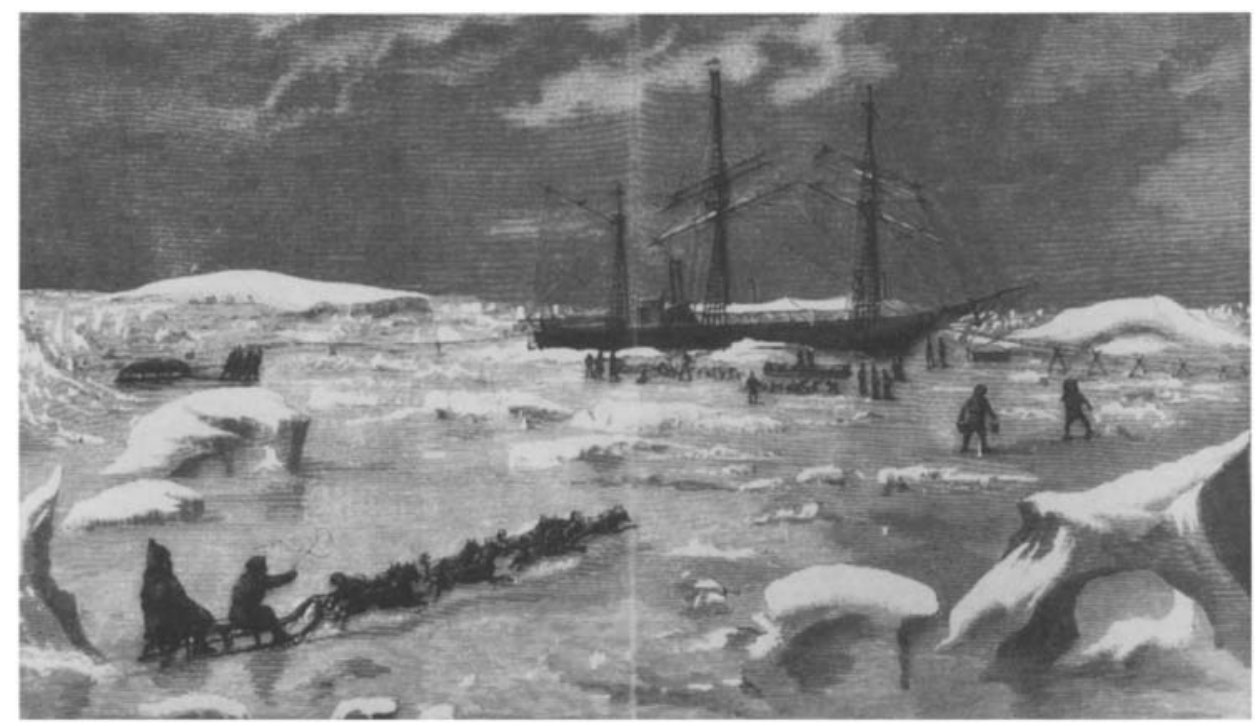

never lost sight of the commercial side of the venture, and insisted that small merchant ships should accompany Vega, to deliver cargo to Siberian ports, and pick up goods for the return journey to Europe. One of the ships, Lena, was a steam-driven vessel, its destination was the city of Yakutsk, over one thousand five hundred kilometers up the Lena River, in east Śiberia. The other two were a small steamer, Fraser, and a small sailing ship, Express, they were bound for the lower Yenisei.

At 2:15 in the morning on July 21, 1878, Vega steamed out of Tromsö, and the expedition was on its way. Nordenskiöld's own account, a two-volume work, The Voyage of the Vega round Asia and Europe, with a historical review of previous journeys along the north coast of the Old World, appeared in Stockholm in 1880 1881. An English translation was published in London in 1885, F.A. Brockhaus published a German translation in 1882. Other translations into Spanish, French, Dutch, Finnish, Russian, Norwegian, and Czech appeared between 1881 and 1883. The present article is based mainly on Nordenskiöld's account, and on Palander's diary.

The trip from Tromsö to Dickson Island, at the mouth of the Yenisei, was smooth and fast. On August 6, the small convoy of ships anchored off Dickson Island, coal was transferred from Express to Vega, and Express and Fraser sailed up the Yenisei, discharged their cargo, picked up cargo bound for Europe, and returned to Göteborg by mid-Ocotober. Vega and Lena started on what was really a trip to the unknown, to round the Taimyr peninsula and its northernmost tip, Cape Chelyuskin. There were no charts of the waters ahead, only simple sketches made by earlier Russian explorers, and the ships had to proceed with caution.

On August 17, waiting for the fog to lift, the two ships were at anchor in a bay on the west side of the Taimyr Peninsula. Anixous to leave messages behind, in case other ships might follow the same route, Nordenskiöld placed a written message in a tin can, and put it in a cairn on shore. In the fall of 1970, a Soviet hydrographic vessel spotted the cairn, and found the message. It was restored to legibility, and presented to the King of Sweden, Gustav VI Adolf, in May, 1971: a logical act, since the message was adressed to his grandfather, Oscar II.

Finally, on August 19, the ships arrived at the dreaded promontory, Cape Chelyuskin, long considered an unsurmountable obstacle for ships bound for eastern Siberian waters. Vega fired five shots from its small cannon, extra rations were issued to the crew, and the anchoring of the ship at latitude 77 degrees 36 minutes 36 seconds north, longitude 103 degrees 25 minutes east, was duly recorded in the log. A major milestone of the Northeast Passage was reached.

Landing on the Cape, the men of the Vega observed the profusion of wildflowers, and a flock of wild geese, coming in from the waters to the north. Nordenskiöld speculated on the possibility on there being land to the north, but there was no time to pursue that line of investigations. In fact, in 1913, Captain Vilkitskii's squadron of Russian naval vessels discovered the archipelago of Severnaya Zemlya, directly north of Cape Chelyuskin.

Continuing eastward, the ships made slow progress. Scientific observations were an important part of the expedition's aims, and observations of water temperatures, currents, weather conditions, and the collecting of specimens of marine life were carried on around the clock. It was on August 27 that the ships, Vega and Lena anchored offshore, near the delta of the Lena River. There the ships parted company, Vega to continue eastward, Lena to sail up river.

Lena reached the town of Yakutsk, its destination, on September 21, discharged its cargo, spent the winter 
there, and returned the next summer to Europe. On arrival in Yakutsk Lena' skipper sent telegrams and letters entrusted to him by Nordenskiöld to Europe. The messages were cheerful and optimistic. All was going according to schedule, the expedition planned to reach Bering Strait within a few weeks, and Japan by late fall. In fact, Nordenskiöld asked that letters be sent to Yokohama, Japan, not an unreasonable request since in those days mail moved swiftly across the world. After these messages reached Europe, though, there was a long silence, for the plans of the expedition did not turn out the way intended.

For a month, Vega sailed along the East Siberian coast. There was fog, there was pack ice, progress was measured in only a few nautical miles per day. Offshore waters were shallow, soundings had to be made continuously, and the ship had to stop and wait for days at a time. Finally, on September 26, they encountered open water, and knowing that Bering Strait was less than 200 kilometers to the east, spirits brightened. They passed the last large bay on the coast, Kolyuchin Bay, and on September 27 Vega tied up to a large ice floe. They found that there was open water ahead, and they knew that the sea was unlikely to freeze so near to Bering Strait. But the next morning the drift ice thickened, and Vega was stuck, frozen in for the winter.

Had the ship anchored a few kilometers further east, they could have continued with ease to Bering Strait. There had also been delays caused by winds and fog and drift ice along the route, all the way from Norway. Above all, there was the need to make scientific observations, especially along the route east of the Yenisei, sailing across uncharted seas. Nordenskiöld was too optimistic to believe that the journey from the Atlantic to the Pacific could be accomplished in a single season; that record was not achieved until 1932.

From the point of view of science, Vega's forced stay of more than nine months on the coast of northeasternmost Siberia proved to be a distinct advantage. The ship was fully equipped as a floating laboratory, there was a highly competent scientific staff on board, and the rich harvest of observations brought back more than justified the inconvenience they endured.

Thanks to Nordenskiöld's careful planning, Vega was fully equipped to face the long Siberian winter. There was plenty of food aboard, sufficiently varied to keep scurvy, the dreaded scourge of Arctic travel under control. There was lime juice and cranberry juice, rum and brandy, and barrels of cloudberries, the berry of the far north rich in vitamins. The ship was well insulated, and there was enough coal aboard to keep it reasonably warm: temperature in living quarters was between 12 and 15 degrees Celsius. A canvas awning was spread over the deck, it froze quickly and provided a roof, allowing men to have sheltered space for exercise.
The ship was anchored to an ice floe, 37 meters long, 23 meters wide, rising 6 meters above water. By the end of winter, ice around Vega was 1.5 meters thick. Drinking water, at first obtained from surface puddles, was melted from snow and ice on land.

Early in October, five structures were built on shore to serve as observatories. One, for geomagnetic measurements, was built by Captain Palander out of ice: the instruments were placed on wooden supports, sunk into holes dug in permafrost. The other structures were built of snow, and housed weather instruments measuring temperatures, wind, humidity, and snowfall. To ensure that magnetic observations were accurate, a separate structure was erected where the men would leave guns and knives while working with instruments.

The observatories were nearly 1.5 kilometers from the ship. Observations were made around the clock: every four hours in October, every hour, November through March, then every four hours again. Observations were made by the scientists and the officers, and two crew members. Knowing the strength of the Siberian blizzards, when visibility is reduced to zero, Nordenskiöld had a fence erected along the route from the ship to the observatories, to guide men back and forth in safety.

In order to keep the crew busy, knowing that idleness in an Arctic winter might lead to illness, as was proved by Palander and Nordenskiöld's experience in Spitsbergen during the winter of 1872-1873, regular duties were carried out by the crew every day, according to navy routine. There was plenty of reading material aboard, and on Sunday evenings the scientific staff gave lectures on a variety of topics. Such strict routine, observed by all aboard the Vega, left little time for idleness, and kept everybody fit, physically and mentally.

There was no doubt in the minds of Vega's crew that they would get through the Siberian winter in good shape. Keeping their vessel safe was their best hope, for the nearest Russian settlements were many hundreds of kilometers away, the ship did not have any dogs to pull sleds, the only means of Arctic travel in the area, and even if they reached a Russian settlement, they could not get any real assistance from the handful of natives and the few Russian officials, who had all they could do to last through the winter themselves.

Messages to home travelled slowly, too. Early in October, a chief of the Chukchi, the native inhabitants of northeasternmost Siberia, visited the ship, and took away a message, since he was on his way to the Russian settlement of Anadyr, on the Bering Sea. That message reached Sweden on May 15. A month earlier, Nordenskiöld's wife got word from the United States that natives reported a ship, frozen in west of Bering Strait, to an American whaling vessel. Finally, in late May, the skipper of Lena, wintering in Yakutsk, sent word that a letter 
from Nordenskiöld, dated February 18, 1879, arrived, reporting that all aboard Vego were well.

Besides the wealth of meteorological and geomagnetic observations, observations of the aurora borealis, and other scientific data gathered by the men on Vega, they also became well acquainted with the native inhabitants of the region, the Chukchi.

The Chukchi living in northeast Siberia are usually thought of as reindeer herders: that remarkable animal, able to survive Arctic winters under the harshest conditions, was indeed the mainstay of the traditional Chukchi way of life, providing food, as well as skins, bone, sinews to be made into clothing and artifacts. During the long winter members of the expedition spent considerable time with the Chukchi, to whom Vega became a regional center of social life: entire families travelled long distances on their dogsleds to meet the strangers on the ship, to get a free meal, and swap their weapons and tools and objects of everyday use for tobacco, pipes, and food. Nordquist, the expedition's Russian interpreter, did not have any occasion to use his knowledge of Russian; instead, he managed to learn quite a bit of the language of the Chukchi, and his observations on the structure of that language are among the earliest scientific contributions to the linguistics of northernmost Asia.

The results of the scientific work carried on by the Vega expedition were first displayed in a spectacular exhibition arranged in the royal palace of Stockholm, on the expedition's return. A series of scientific studies, dealing with the animal and vegetal world of Northern Asia, with its climate and hydrography, with the oceanography of Arctic seas, with palaeontology, geophysics, terrestrial magnetism, as well as with the anthropology and ethnography of northeast Siberia, representing the contributions of twenty-eight scholars from Sweden and from other European countries, were published in five volumes, under the title:

"Scientific observations of the Vega expedition, compiled by participants in the voyage and other researchers, edited by A.E. Nordenskiöld".

The volumes, published in part with support from the Swedish state, in part subventioned by the expedition's principal patron, Oscar Dickson, appeared, in Swedish, between 1882 and 1887. A German translation of essays in the first volume came out in Leipzig, in 1882-1883. Nordenskiöld also edited a "popular" volume, that was translated into German and appeared, published by Brockhaus, in 1885: "Studien und Forschungen veranlasst durch meine Reisen im hohen Norden".

The scientific results of the Vega expedition represent one of the first major contributions to our knowledge of polar lands. Nordenskiöld had prepared himself well for the task, since scientific objectives determined his earlier voyages to the Arctic, and he was a true natural scientist, aware of the interests of other branches of science, and eager to assemble the greatest possible number of observations during the Vega expedition.

The meteorological and oceanographic results alone, dealing to a large extent with those waters north of Siberia that had not before been subject to careful and methodical observation, would justify the work done by the Vega staff. Observations were taken every four hours of barometric pressure, air temperature and humidity, direction and velocity of winds, degree of cloudiness, and precipitations. Depth of sea, temperature masurements at different depths, tidal movement were also observed at four-hour intervals.

The geological work dealt with the surface geology of as many segments of the Siberian coastline as could be observed, including rock specimens. Algae, the special interest of Kjellman, and lichens, the special concern of Almquist, were carefully collected and identified. Stuxberg paid particular attention to invertebrate zoology. Among the many specimens of animal life brought back by the expedition there were several complete skeletons of an extinct species of marine mammal, the sea cow, Rhytina Stelleri, described a century earlier by the German naturalist Steller, in the Bering Sea area.

At last, spring came, heralded by the arrival of birds, but the ship remained immobile in the ice. It was not until July 18, 1979, nine months and twenty days after Vega was frozen in, that the ice broke up, and that afternoon, with the help of the ship's engine, Vega left its winter quarters. At 11 o'clock in the morning the next day, it entered Bering Strait.

"Thus at last the goal was reached", wrote Nordenskiöld, "that so many nations struggled for, ever since Sir Hugh Willoughby ushered in the long series of voyages to the Northeast .... it was granted to this and to previous Swedish expeditions to open an ocean to navigation, and to offer nearly half a continent the possibility of a seaway to the world ocean."

Some months earlier, while Vega was still ice-bound, Nordenskiöld, prepared a memorandum "On the Possibility of Commercial Navigation in the Waters off Siberia". In it, he correctly predicted that much of the traffic on this Northern Seaway was likely to take place between Europe, the $\mathrm{Ob}^{\prime}$, and the Yenisei in the western, between the Lena and the Pacific in the eastern segment. One of the several prophetic notes in his memorandum states:

". . . our experience proves that it will always be possible to ship to the Lena by steamer heavy machinery and other goods that cannot be easily transported by sleds or carriages".

The results of the Vega expedition thus encompass both scientific and practical results. Some years later, in 1893, after having consulted Nordenskiöld, the Russian government used the northern sea route and the Yenisei River to ship rails for the Trans-Siberian railroad as far as Krasnoyarsk. In 1897, the Russian Navy's foremost 
advocate of Arctic shipping, Admiral Makarov, again consulted Nordenskiöld on the problem of building icebreakers strong enough to open passage for ships along the Siberian coast. But the true development of the Northern Sea Route had to wait until after the Russian Revolution, today it is part of the Soviet Union's network of merchant shipping.

The latter part of July and the month of August, 1879, were spent by Vega sailing around the Bering Sea, collecting more information on marine biology, picking up some choice examples of Eskimo arts and crafts, and eventually arriving in Japan early in September. The return journey was via Hongkong, Borneo, Singapore, Ceylon, Aden, the Suez Canal to the Mediterranean. Their reception in Italy and France was a series of banquets and festive occasions, but the climax of the voyage occurred when, on the evening of April 24, 1880, Vega reached Stockholm. Nothing like the homecoming of Vega had ever occurred in the life of the Swedish capital. People came from all over Sweden, the entire harbor was bedecked by lights. Nordenskiöld and his staff were received by King Oscar in the royal palace: Nordenskiöld was created a baron of the realm, Louis Palander and Oscar Dickson were elevated to the nobility, all of the scientific staff and the officers were decorated. Nordenskiöld was the man of the hour, feted at home and abroad.

\section{Bibliographical note}

YMER, the Journal of the Swedish Society for Anthropology and Geography, published a special memorial issue on Nordenskiöld in 1902 (vol. 22, no. 2). Besides a brief biography, and studies on Nordenskiöld's Arctic voyages, on his contributions to geology, mineralogy, historical geography and history of cartography, a bibliography of his writings by J.M. Hulth (pp. 277-303) was also included.
To lead a normal and productive life after such climatic events was not an easy task. Yet, for the remaining two decades of his life, Adolf Nordenskiöld continued to work as an elder statesman of polar exploration, a scientiest of great distinction. He actually made one more journey to the Arctic, to Greenland. Perhaps his geatest achievement was his series of studies in the history of cartography, originally motivated by his research on the history of the Northeast Passage. His two books, "Facsimile atlas to the early history of cartography", published in 1889 in Swedish and English, and "Periplus: An essay on the early history of charts and sailing directions", published again in both Swedish and English, remain to this day among the most authoritative studies in the field.

The clearest tribute paid to his achievements on the Vega expedition, and on his other sallies to the Arctic was that of Gustav Retzius, his successor in the Swedish Academy, in 1902, a year after Nordenskiöld's death:

"It was his highest achievement as scientist that he changed Arctic research from a vague search for discovery to an undertaking based on scientific foundation, well planned, well prepared and succesfully carried out: a methodical, systematic, scientific research undertaking."

Two biographies of Nordenskiöld were published in Swedish, by Sven Hedin, Adolf Erik Nordenskiöld (Stockholm, 1926), and by Henrik Ramsay, Nordenskiöld Sjöfararen (Stockholm, 1950). A biography in English, The Arctic Voyages of Adolf Erik Nordenskiöld, by the English translator of The Vega Voyage, Alexander Leslie, appeared in London, in 1879.

Northeast Passage“ Adolf Erik Nordenskiöld, his Life and Times, by the author of this article, was published in Amsterdam by N. Israel, in 1973. The quotations in this article are taken from that work, with the kind permission of the publisher. 